Vol. 9 (4): 709-716 (2019)

\title{
LEAD MOBILITY IN THE SOIL OF DIFFERENT AGROECOSYSTEMS
}

\author{
Valeria Bondar $^{1 *}$, Natalia Makarenko ${ }^{1}$, Lyudmyla Symochko ${ }^{2,3}$ \\ ${ }^{I}$ National University of Life and Environmental Sciences of Ukraine, Heroiv Oborony, Str.15, 03041 Kyiv, Ukraine; \\ ${ }^{2}$ Faculty of Biology, Uzhhorod National University, Voloshyna Str. 32, 88000, Uzhhorod, Ukraine; \\ ${ }^{3}$ Institute of Agroecology and Environmental Management, 12, Metrologichna Str. Kyiv 03143, Ukraine; \\ *Corresponding Author Valeria Bondar, e-mail address: lera bond@email.ua;
}

Received June 2019; Accepted August 2019; Published October 2019;

DOI: https://doi.org/10.31407/ijees9416

\begin{abstract}
Lead $(\mathrm{Pb})$ is a widespread pollutant presented in soil, by various compounds. However, only mobile forms represent a danger to living organisms. The mobile compounds are those extracted with 0.1 and $1.0 \mathrm{HCl}$. Soil indexes like the content of particles less than $0.001 \mathrm{~mm}$ (clay), soil organic matter (SOM) content, $\mathrm{pH}$ status of the soil solution significantly affect the mobility of lead. Application of mineral and organic fertilizers can enhance or reduce the mobility of lead in soil as well. The influence of fertilizers on the mobility of lead, as well as the peculiarities of its translocation into plants, was investigated at long-term-field experiments in three main climatic zones of Ukraine (Polissya, Forest-steppe, Steppe). We found that the soil parameters had the influence on lead mobility were in the following sequence: clay content $>\mathrm{SOM}>$ soil $\mathrm{pH}$. There was a strong inverse correlation between lead mobility and soil parameters $(\mathrm{r}=0.821-0.962)$. Application of mineral fertilizers increased the content of lead mobile forms in soil (by 7-24\%), whereas organic fertilizers contributed to its decrease. Crops were ranged by the ability for lead accumulation in the following order: clover $>$ sugar beets > corn > sunflower> winter wheat. Furthermore, mineral fertilizers contributed significantly to lead translocation from the soil to crops, while the influence of organic fertilizers on this process was insignificant.
\end{abstract}

Keywords: crop, environmental risk, fertilizers, lead mobility, soil 